\title{
Penerapan Model Pembelajaran Cooperative Learning Tipe Jigsaw Untuk Meningkatkan Hasil Belajar Fisika Siswa Kelas XII IPA 3 SMA Negeri 3 Bengkalis
}

\author{
Nurhadi \\ SMA Negeri 3 Bengkalis \\ e-mail: \\ adywh75@gmail.com
}

\begin{abstract}
.
This research is a classroom action research (PTK) with the application of a jigsaw type cooperative learning learning model to improve physics learning outcomes. The Jigsaw type cooperative learning model is a cooperative learning model with students learning in small groups consisting of 4-6 people heterogeneously, working together, positively interdependent and responsible for completing the part of learning material that must be learned and delivered to group members. The problem to be solved is the low physics learning outcomes of class XII IPA 3 in Bengkalis Public High School 3 involving 20 students. This study consisted of 2 cycles, in each cycle consisting of four stages, namely Planning, Implementation, Observation and Reflection. In the pre-cycle process, the percentage of student learning completeness is $25.00 \%$, then after learning the first cycle with the application of the Jigsaw Cooperative Learning Type model there is an increase in the percentage of learning completeness to $55.00 \%$. And in the second cycle managed to achieve a significant percentage of completeness of $85.00 \%$. The results showed that there was an increase in student physics learning outcomes as the Jigsaw Cooperative Learning Learning model was implemented.
\end{abstract}

Keywords: Cooperative Learning Model, Jigsaw, Physics Learning Outcomes

Penelitian ini merupakan penelitian tindakan kelas (PTK) dengan penerapan model pembelajaran cooperative learning tipe jigsaw untuk meningkatkan hasil belajar fisika. Model pembelajaran cooperative learning tipe Jigsaw merupakan model pembelajaran kooperatif dengan siswa belajar dalam kelompok kecil terdiri dari 4-6 orang secara heterogen, bekerja bersama, saling bergantung positif dan bertanggung jawab atas ketuntasan bagian materi pembelajaran yang harus dipelajari dan disampaikan kepada anggota kelompok. Masalah yang hendak dipecahkan adalah rendahnya hasil belajar fisika kelas XII IPA 3 di SMA Negeri 3 Bengkalis yang melibatkan 20 orang siswa. Penelitian ini terdiri dari 2 siklus, pada setiap siklus terdiri dari empat tahapan, yaitu Perencanaan, Pelaksanaan, Observasi dan Refleksi. Pada proses prasiklus, persentase ketuntasan belajar siswa yaitu sebesar $25,00 \%$, kemudian setelah dilaksanakan pembelajaran siklus I dengan penerapan model pembelajaran Cooperative Learning Tipe Jigsaw ada peningkatan persentase ketuntasan belajar menjadi 55,00\%. Dan pada siklus II berhasil mencapai persentase ketuntasan yang signifikan sebesar $85,00 \%$. Hasil penelitian menunjukkan bahwa terjadi peningkatan hasil belajar fisika siswa seiring diterapkannya model pembelajaran Cooperative Learning Tipe Jigsaw.

Kata Kunci: Cooperative Learning, Jigsaw, Hasil Belajar Fisika. 


\section{PENDAHULUAN}

SMA Negeri 3 Bengkalis Kecamatan Bengkalis Kabupaten Bengkalis merupakan sekolah yang telah memiliki akreditasi $\mathrm{A}$, namun masih memiliki masalah belajar pada mata pelajaran fisika. Berdasarkan observasi melalui proses pembelajaran di kelas XII IPA 3 SMA Negeri 3 Bengkalis terdapat beberapa permasalahan. Pertama, siswa tidak menyiapkan diri sebelum pembelajaran dimulai walaupun materi pelajaran yang akan diajarkan pada pertemuan berikutnya sudah diketahui. Kedua, aktivitas siswa dalam proses pembelajaran masih rendah dapat dilihat dari kurangnya respons siswa ketika diberikan permasalahan oleh guru. Ketiga, siswa belum memiliki ketertarikan terhadap pembelajaran fisika yang dapat dilihat dari tingkat keaktifan siswa dan tingkat perhatian siswa pada saat pelajaran berlangsung. Keempat, rata-rata hasil ulangan kelas XII IPA 3 hanya mencapai 49,80 dengan 75,00 \% siswa yang masih mendapat nilai di bawah KKM (Kriteria Ketuntasan Minimum) yang tetapkan (72).

Keaktifan siswa dan ketertarikan yang masih kurang dalam pembelajaran merupakan salah satu indikator bahwa siswa masih kurang memiliki motivasi belajar. Menurut dikutip Siregar dan Nara (2010 : 52) menyatakan bahwa diantara tiga faktor, yaitu latar belakang keluarga, kondisi atau konteks sekolah dan motivasi, maka faktor yang terakhir merupakan prediktor yang paling baik untuk prestasi belajar. Selanjutnya pendapat Koeswara (dalam Dimyati \& Mujiono, 2006 : 80) bahwa motivasi dipandang sebagai dorongan mental untuk menggerakkan dan mengarahkan prilaku manusia termasuk perilaku pelajar yang terkandung adanya keinginan mengaktifkan, menggerakkan, menyalurkan dan mengarahkan sikap perilaku individu belajar. Untuk meningkatkan motivasi belajar maka proses pembelajaran harus menerapkan model pembelajaran yang sesuai. Pembelajaran harus dapat mengkondisikan kegiatan kelas sedemikian rupa sehingga siswa dapat berdiskusi dan berdebat mendalami konsep. Pembelajaran seperti ini dapat membuat siswa benar-benar memahami konsep, saling menjaga dan saling mengambil tanggung jawab satu sama lain. Pembelajaran sedemikian terdapat pada pembelajaran kooperatif.

Salah satu model pembelajaran kooperatif adalah pembelajaran cooperative learning tipe jigsaw. Model pembelajaran cooperative learning tipe jigsaw merupakan model pembelajaran kooperatif dengan siswa belajar dalam kelompok kecil yang terdiri dari empat sampai enam orang secara heterogen dan bekerja bersama, saling bergantung positif, dan bertanggung jawab atas ketuntasan bagian materi pembelajaran yang harus dipelajari dan disampaikan kepada anggota kelompok yang lain (Slavin dalam Arends, 2008 : 137).

Jigsaw mengutamakan kerjasama kelompok dan diskusi untuk mendapatkan suatu penghargaan (reward). Adanya penghargaan ini diharapkan dapat memotivasi siswa untuk belajar dan memiliki tanggung jawab untuk mampu menerangkan materi kepada temannya sehingga kelompoknya menjadi juara. Dengan model pembelajaran cooperative learning tipe Jigsaw diharapkan hasil belajar siswa juga meningkat.

Atas dasar fenomena ini, penulis melakukan Penelitian Tindakan Kelas (PTK) dengan judul Penerapan Model Pembelajaran Cooperatif Learning Tipe Jigsaw Untuk Meningkatkan Hasil Belajar Fisika Siswa Kelas XII IPA 3 SMA Negeri 3 Bengkalis. Tujuan penelitian ini adalah untuk mendeskripsikan apakah penerapan model pembelajaran cooperative learning tipe jigsaw dapat meningkatkan hasil belajar fisika siswa kelas XI IPA 3 SMA Negeri 3 Bengkalis.

Belajar merupakan suatu proses yang dilakukan individu untuk memperoleh suatu perubahan tingkah laku yang baru secara keseluruhan sebagai hasil pengalaman individu itu sendiri dalam interaksi dengan lingkungannya berupa pengamatan, pengalaman ataupun peniruan individu terhadap individu lain (Aunurrahman, 2011 : 35). Sementara Winkel (1996 : 53) menjelaskan bahwa belajar adalah suatu aktivitas mental atau psikis yang berlangsung dalam interaksi aktif dengan lingkungannya yang menghasilkan perubahan-perubahan dalam pengetahuan, keterampilan dan nilai sikap. Sedangkan Sardiman (2012 : 20). Berpendapat bahwa belajar itu senantiasa merupakan perubahan tingkah laku atas penampilannya dengan serangkaian kegiatan misalnya 
dengan membaca, mendengarkan, meniru dan lain sebagainya. Selanjutnya Sardiman (2012: 25) menjelaskan lagi ada tiga tujuan belajar. Pertama, untuk mendapatkan pengetahuan; ditandai dengan adanya kemampuan berpikir, pengetahuan juga bisa didapat dari mana saja baik itu sekolah formal maupun informal. Kemampuan berpikir tidak dapat berkembang tanpa bahan pengetahuan dan sebaliknya kemampuan berpikir akan memperkaya pengetahuan. Kedua, penanaman konsep dan keterampilan; penanaman konsep memerlukan keterampilan yang bersifat jasmani maupun rohani. Keterampilan jasmani adalah keterampilan yang dapat dilihat, diamati sehingga akan menitik beratkan pada keterampilan gerak anggota tubuh seseorang yang sedang belajar. Sedangkan keterampilan rohani lebih rumit karena bersifat lebih abstrak menyangkut persoalanpersoalan, penghayatan dan keterampilan berpikir serta kreativitas untuk menyelesaikan suatu masalah. Ketiga, pembentukan sikap; meliputi mental dan perilaku siswa tidak terlepas dari penanaman nilai-nilai, hal ini dibutuhkan peran tenaga pengajar baik guru atau dosen yang tidak sekedar sebagai pihak yang mentransfer pengetahuan tetapi juga sebagai pendidik yang memindahkan nilai-nilai tersebut kepada siswanya.

Menurut Joyce \& Weil dalam Rusman (2012 : 133) menyatakan bahwa model pembelajaran adalah suatu rencana atau pola yang dapat digunakan untuk membentuk kurikulum (rencana pembelajaran jangka panjang), merancang bahan-bahan pembelajaran dan membimbing pembelajaran di kelas atau yang lain untuk mencapai tujuan pembelajaran. Sedangkan menurut Komalasari (2011 : 57), model pembelajaran pada dasarnya merupakan bentuk pembelajaran yang tergambar dari awal sampai akhir yang disajikan secara khas oleh guru. Sementara itu Suprijono (2011 : 46) berpendapat bahwa model pembelajaran dapat didefinisikan sebagai kerangka konseptual yang melukiskan prosedur sistematis dalam mengorganisasikan pengalaman belajar untuk mencapai tujuan belajar. Guru sering mendapat kesulitan di dalam proses belajar mengajar di kelas. Kesulitan yang dialaminya ini membuat guru mencoba mencari tahu apa penyebabnya.

Banyak rencana, teknik serta model yang coba diterapkan guru. Model pembelajaran merupakan salah satu pendekatan dalam rangka menyiasati perubahan perilaku secara adaptif maupun generatif (Hanafiah \& Suhana, 2009 : 41). Dengan demikian dapat disimpulkan bahwa model pembelajaran merupakan suatu rencana atau kerangka yang dapat digunakan oleh guru untuk merencanakan pengajaran yang bermakna sehingga tujuan pembelajaran tercapai serta terdapat perubahan perilaku siswa secara adaptif maupun generatif.

Cooperative learning berasal dari kata cooperative yang artinya mengerjakan sesuatu secara bersama-sama dengan saling membantu satu sama lainnya dalam satu kelompok atau satu tim (Isjoni, 2011 : 15). Menurut Slavin dalam Komalasari (2011 : 62) menjelaskan cooperative learning merupakan suatu strategi pembelajaran dimana siswa belajar dan bekerja dalam kelompokkelompok kecil secara kolaboratif yang anggotanya terdiri dari 2-5 orang, dengan struktur kelompoknya yang bersifat heterogen. Keberhasilan belajar dari kelompok, tergantung pada kemampuan dan aktivitas anggota kelompok, baik secara individual maupun secara kelompok.

Karakteristik model pembelajaran cooperative learning menurut Rusman (2012 : 207) ada tiga, yaitu : a). pembelajaran secara tim; pembelajaran kooperatif adalah pembelajaran yang dilakukan oleh tim untuk mencapai tujuan. Tim harus mampu membuat setiap siswa untuk belajar sehingga saling membantu dalam mencapai tujuan pembelajaran. b). kemauan bekerja sama; keberhasilan pembelajaran kooperatif ditentukan oleh keberhasilan kelompok, oleh karenanya prinsip bekerja sama perlu ditekankan dalam kooperatif dalam mencapai hasil yang optimal. c). keterampilan bekerja sama; ini dipraktikkan dalam aktivitas kegiatan belajar mengajar secara berkelompok. Siswa perlu didorong untuk sanggup berinteraksi dan berkomunikasi dengan anggota lain yang bertujuan mencapai suatu penghargaan bersama dalam satu tim kelompok.

Adapun prosedur atau sintaks model cooperative learning menurut Rusman (2012 : 212-213) meliputi empat tahapan yaitu (1) penjelasan materi; tahapan penyampaian pokok-pokok materi pelajaran sebelum siswa belajar dan berinteraksi di dalam kelompok agar siswa memiliki 
pemahaman yang sama dan jelas terkait pokok materi pelajaran yang akan dibahas. (2) belajar kelompok; ini merupakan kelanjutan dari tahapan penjelasan materi setelah itu guru membentuk siswa menjadi beberapa kelompok untuk bekerja sama membahas materi yang telah ditentukan. (3) penilaian; tahapan yang dilakukan pada proses pembelajaran dengan penilaian non tes maupun tes yang bertujuan untuk mengukur hasil belajar yang dicapai oleh siswa. Setiap informasi yang didapatkan dari hasil penilaian dijadikan sumber autentik dan dipadukan untuk memberikan keputusan akhir terhadap hasil belajar yang dicapai oleh setiap siswa. (4) pengakuan tim; tahapan dimana guru menetapkan tim (kelompok) yang paling menonjol atau berprestasi dalam proses pembelajaran dengan pemberian penghargaan, atau pengakuan yang diharapkan akan memotivasi kelompok lain untuk terus meningkatkan prestasinya dalam kegiatan pembelajaran.

Model cooperative learning memiliki banyak sekali tipe yang dapat digunakan dalam pembelajaran. Isjoni (2011 : 50) mengemukakan bahwa dalam cooperative learning terdapat beberapa variasi model yang dapat diterapkan, yaitu diantaranya: (1) student team achievement division (STAD), (2) jigsaw, (3) group investigation, (4) rotating trio exchange, (5) group resume, (6) numbered head together (NHT), (7) take and give dan lain-lain. Dari beberapa model pembelajaran tersebut, salah satu model pembelajaran alternatif yang diterapkan dalam penelitian ini adalah model pembelajaran cooperative learning tipe jigsaw.

Metode pembelajaran cooperative learning tipe jigsaw dikembangkan dan diuji oleh Elliot Aronson dan rekan-rekan sejawatnya (Slavin, 2005 : 236). Metode ini para siswa dari suatu kelas dikelompokkan menjadi beberapa tim belajar yang beranggotakan 4-6 orang secara heterogen. Guru memberikan bahan ajar dalam bentuk teks kepada setiap kelompok dan setiap siswa dalam satu kelompok bertanggungjawab mempelajari satu porsi materinya. Para anggota dari tim-tim yang berbeda tetapi membahas topik yang sama bertemu untuk belajar dan saling membantu dalam mempelajari topik tersebut (kelompok ahli). Hal sejalan juga dikatakan oleh Slavin dalam Arends (2008 : 137) bahwa model pembelajaran cooperative learning tipe jigsaw merupakan model pembelajaran kooperatif, dengan siswa belajar dalam kelompok kecil yang terdiri dari 4-6 orang siswa secara heterogen dan bekerjasama saling ketergantungan positif dan bertanggungjawab atas ketuntasan bagian materi pelajaran yang harus dipelajari serta menyampaikan materi tersebut kepada anggota kelompok.

Menurut Rusman (2012 : 218) pelaksanaan pembelajaran cooperative learning tipe jigsaw dilakukan melalui langkah-langkah sebagai berikut : pertama, siswa dikelompokkan dengan anggota lebih kurang 4 orang (kelompok asal), kemudian tiap orang dalam tim diberi materi dan tugas yang berbeda, lalu anggota dari tim yang berbeda dengan penugasan yang sama membentuk kelompok baru (kelompok ahli) untuk mendiskusikan materi mereka, setelah kelompok ahli berdiskusi, tiap anggota tim kembali ke kelompok asal dan menjelaskan kepada anggota kelompoknya tentang subbab yang mereka kuasai secara bergantian dan yang lainnya memperhatikannya, kemudian tiap tim ahli mempresentasikan hasil diskusi, guru membimbing dan mengevaluasi, yang terakhir penutup.

Kelebihan model pembelajaran cooperative learning tipe jigsaw menurut Arends $(2008: 23)$ adalah kelas Jigsaw merupakan cara pembelajaran materi yang efisien, karena dibagi menjadi beberapa kelompok dan masing-masing kelompok mempelajari salah pokok bahasan; proses pembelajaran pada kelas Jigsaw melatih kemampuan pendengaran, dedikasi dan empati dengan cara memberikan peran penting kepada setiap anggota kelompok dalam aktivitas akademika; mengembangkan kemampuan siswa untuk mengungkapkan ide maupun gagasan untuk memecahkan suatu masalah; meningkatkan kemampuan sosial siswa yaitu percaya diri dan hubungan interpersonal yang positif; siswa lebih aktif dalam berpendapat dan menjelaskan materi kepada masing-masing anggota kelompok; siswa diajarkan bagaimana bekerja sama dalam kelompok. Sedangkan kelemahan model pembelajaran cooperative learning tipe jigsaw adalah siswa yang aktif akan lebih mendominasi diskusi dan cenderung mengontrol jalannya diskusi; siswa yang lambat akan kesulitan dalam menyampaikan atau mempresentasikan materi kepada anggota 
kelompok; siswa cerdas cenderung merasa cepat bosan; siswa yang tidak terbiasa berkompetisi akan kesulitan mengikuti proses pembelajaran; kondisi kelas yang kurang kondusif akan membuat siswa sulit berkonsentrasi dalam menyampaikan pembelajaran; jika jumlah anggota kelompok kurang akan menimbulkan masalah, misalnya jika ada anggota yang hanya membonceng atau pasif dalam menyelesaikan tugas-tugas dalam diskusi tersebut; membutuhkan waktu lebih lama dalam penataan ruang yang belum terkondisi dengan baik dan dalam proses pembelajaran.

Menurut Abdurrahman (2003 : 37) hasil belajar adalah kemampuan yang diperoleh siswa setelah melalui kegiatan belajar. Suprijono (2011 : 20) berpendapat pula hasil belajar adalah polapola perbuatan, nilai-nilai, pengertian-pengertian, sikap-sikap, dan keterampilan. Sementara Nana Sudjana (1990 : 67) mengemukakan hasil belajar merupakan kemampuan yang dimiliki siswa setelah ia menerima pengalaman belajar. Ada tiga faktor yang mempengaruhi hasil belajar siswa menurut Syah (2002 : 23) yaitu : pertama, faktor internal (faktor dari dalam siswa), yakni keadaan/kondisi jasmani dan rohani siswa, misalnya penglihatan, pendengaran, struktur tubuh dan sebagainya. Kedua, faktor eksternal (faktor dari luar siswa), yakni kondisi lingkungan di sekitar siswa, misalnya lingkungan sosial (keluarga, masyarakat/kelompok), lingkungan fisik (fasilitas rumah, fasilitas belajar). Ketiga, faktor pendekatan belajar, yakni jenis upaya belajar siswa yang meliputi strategi dan metode yang digunakan siswa untuk melakukan kegiatan pembelajaran memahami materi-materi pelajaran.

Berdasarkan uraian di atas, hasil belajar siswa merupakan tujuan akhir dalam belajar yang berwujud nilai hasil belajar siswa, baik sikap, psikomotor maupun pengetahuan yang diperoleh berdasarkan pengalaman belajar yang mengakibatkan adanya proses perubahan tingkah laku. Siswa yang berhasil dalam belajar adalah siswa yang berhasil mencapai tujuan-tujuan pembelajaran dengan prestasi nilai tinggi.

\section{METODOLOGI}

Penelitian ini diadakan di SMA Negeri 3 Bengkalis kelas XII IPA 3 berjumlah 20 orang dengan pertimbangan bahwa kelas tersebut kemampuan nilai hasil belajar siswa lebih rendah dibanding dengan kelas lain. Penelitian ini diadakan selama 3 bulan yaitu dari bulan Januari sampai dengan bulan Maret tahun 2018 dalam 2 siklus dan setiap siklus terdiri atas 2 kali pertemuan sesuai dengan empat tahapan setiap siklus, yaitu tahap perencanaan (planning), tahap pelaksanaan tindakan (acting), tahap pengamatan (observing) dan tahap refleksi (reflecting).

Adapun persiapan penelitian dengan cara menyusun langkah-langkah kongkrit yang akan digunakan dalam proses pembelajaran termasuk mengkaji SK, KD dan materi pembelajaran kemudian menyusun instrumen untuk penelitian dan terakhir menyusun RPP. Teknik pengumpulan data penelitian ini menggunakan teknik tes tertulis dan instrumen pengumpulan data berupa lembar kerja siswa atau lembar hasil belajar siswa (lembar tes).

Data yang diperoleh dianalisis dengan menggunakan analisis deskriptif (analisis ketuntasan hasil belajar siswa) bertujuan untuk memperlihatkan penguasaan dan ketuntasan hasil belajar siswa. Tingkat keberhasilan belajar siswa secara individu untuk pelajaran fisika di kelas XII IPA 3 berdasarkan Kriteria Ketuntasan Minimal (KKM) yaitu 72. Sedangkan ketuntasan hasil belajar secara klasikal sebesar 85\%. Persentase Ketuntasan Belajar Siswa Individu (KBSI) dihitung dengan menggunakan rumus yang diberikan oleh Tim Pustaka Yustisia (2008) :

$$
\text { KBSI }=\frac{\text { Skor yang Diperoleh Siswa }}{\text { Skor Maksimal }} \times 100 \%
$$

Sedangkan Persentase Ketuntasan Belajar Siswa Klasikal (KBSK) dapat ditentukan dengan rumus yang diberikan oleh Depdiknas (2004): 


$$
\text { KBSK }=\frac{\sum \text { Siswa yang Tuntas }}{\sum \text { Seluruh Siswa }} \times 100 \%
$$

\section{TEMUAN DAN PEMBAHASAN}

Sebelum melakukan siklus, peneliti mengumpulkan data awal berupa daftar nama siswa dan nilai nilai ulangan harian (UH) siswa kelas XII IPA 3 pada materi sebelumnya. Pada proses prasiklus, siswa terlihat tidak menyiapkan diri sebelum pembelajaran walaupun materi pelajaran pertemuan berikutnya sudah diketahui, kurangnya respons siswa ketika diberikan permasalahan dan belum memiliki ketertarikan belajar fisika akibatnya keaktifan dan perhatian siswa masih kurang pada saat pembelajaran berlangsung. Terbukti dari hasil ulangan harian hanya terdapat 5 $(25,00 \%)$ orang siswa yang tuntas di atas KKM 72 . Sementara 15 (75\%) orang siswa tidak tuntas.

\section{Siklus I}

Siswa melaksanakan tes awal. Setelah selesai, guru membagi siswa dalam 5 kelompok dengan masing-masing kelompok beranggotakan 4 orang siswa berdasarkan jumlah ketuntasan siswa hasil tes sebelumnya. Kelompok ini disebut Kelompok Asal, lalu guru membagikan LKS dengan submateri yang berbeda dalam satu kelompok, siswa mempelajari submateri LKS tersebut. Setelah waktu ditentukan, guru membagi siswa dalam kelompok baru yaitu Kelompok Ahli dengan cara siswa yang mendapat nomor LKS atau submateri yang sama berkumpul menjadi satu kelompok baru (Kelompok Ahli). Siswa berdiskusi dalam kelompok tersebut membahas materi secara bersama-sama. Guru memperhatikan jalannya diskusi. Kemudian siswa kembali duduk di Kelompok Asal untuk menjelaskan submateri yang telah dibahas dari Kelompok Ahli secara bergantian kepada temannya. Pada pertemuan 2, siswa melanjutkan diskusi kelompok asal dengan saling menjelaskan materi secara bergantian. Guru senantiasa mengawasi jalannya diskusi kelompok. Kemudian Guru meminta salah satu perwakilan dari kelompok mempresentasikan hasil diskusi untuk menguji keberhasilan model pembelajaran cooperative learning tipe jigsaw. Guru memberi reward pada kelompoknya terbaik. Siswa dibimbing menarik simpulan. Selanjutnya guru memberikan soal evaluasi (Tes Akhir Siklus I) dalam waktu 30 menit. Hasil tes sebagai berikut :

Tabel 1. Ketuntasan Hasil Belajar Siklus I

\begin{tabular}{cccc}
\hline No & Hasil Belajar & Jumlah & Persentase \\
\hline 1 & Tuntas & 11 & 55 \\
\hline 2 & Tidak Tuntas & 9 & 45 \\
\hline & Jumlah & 20 & 100 \\
\hline
\end{tabular}

Tabel 1. di atas menunjukkan bahwa jumlah siswa yang belum tuntas dalam belajar mengalami penurunan yaitu dari $14(70,00 \%)$ orang siswa menjadi 9 (45,00\%) orang siswa. Sedangkan siswa yang telah mencapai ketuntasan dalam belajar meningkat dari $6(30,00 \%)$ orang siswa pada tes awal siklus I menjadi $11(55,00 \%)$ orang siswa pada tes akhir siklus I. Namun demikian hasil belajar siswa belum seperti yang diharapkan dengan kondisi masih lebih banyak siswa yang belum tuntas dalam belajar. Oleh karena itu perlu pelaksanaan siklus II dalam meningkatkan hasil belajar siswa.

Hasil pengamatan siswa dalam pembelajaran, yaitu suasana kelas sedikit ramai/ribut saat sedang melakukan diskusi kelompok, masih banyak siswa terlihat diam ketika guru memberikan penjelasan materi, ada siswa kurang aktif belajar dalam kelompok, hal ini terbukti ada siswa yang hanya diam dan bermain dengan temannya, dalam mengerjakan soal tes awal dan tes akhir ada siswa yang mencontek karena merasa kurang percaya diri dengan kemampuannya, siswa belum memaksimalkan waktu dalam menyelesaikan tugas, siswa kurang percaya diri dengan kemampuan 
yang dimilikinya baik dalam presentasi maupun dalam mengerjakan soal tes, di akhir pembelajaran masih jarang siswa bertanya mengenai materi yang belum dipahami.

Hasil pengamatan aktivitas guru, yaitu guru masih kurang maksimal dalam mengkondisikan kelas yang kondusif, guru aktif memantau kegiatan pelaksanaan diskusi di dalam kelas dengan berkeliling saat siswa diskusi kelompok, guru kurang memberikan motivasi kepada siswa agar lebih aktif, pengelolaan waktu masih belum efektif dan efisien.

Dari hasil pengamatan pembelajaran harus dilakukan tindakan perbaikan untuk meningkatkan hasil belajar, berupa berusaha lebih baik memotivasi siswa untuk aktif dan saling bekerjasama dalam kelompok diskusi. Pada saat pembelajaran berlangsung kontak pandang guru terhadap siswa tidak hanya tertuju pada seorang/kelompok saja, tetapi menyeluruh untuk membuat siswa memahami materi yang dipelajari. Meningkatkan pengelolaan kelas dalam pembelajaran dan menggunakan waktu dengan efektif dan efisien.

\section{Siklus II}

Guru membagi siswa menjadi lima kelompok asal yang heterogen beranggotakan empat orang siswa tiap kelompok. Guru membagikan LKS dengan submateri yang berbeda dalam satu kelompok, siswa mempelajari submateri LKS tersebut. Setelah waktu ditentukan selesai, guru membagi siswa dalam Kelompok Ahli dengan cara siswa yang mendapat nomor LKS atau submateri yang sama berkumpul menjadi satu kelompok baru (Kelompok Ahli). Siswa berdiskusi dalam kelompok tersebut membahas materi secara bersama-sama. Guru memperhatikan jalannya diskusi. Kemudian siswa kembali duduk di Kelompok Asal untuk menjelaskan/mempresentasikan submateri yang telah dibahas kepada temannya secara bergantian. Pada pertemuan berikutnya, siswa melanjutkan diskusi kelompok asal dengan saling menjelaskan/mempresentasikan materi secara bergantian. Guru senantiasa mengawasi jalannya diskusi kelompok. Kemudian Guru meminta salah satu perwakilan dari kelompok mempresentasikan hasil diskusi untuk menguji keberhasilan model pembelajaran cooperative learning tipe jigsaw. Guru lebih memotivasi siswa dalam belajar dan memberi reward. Siswa bersama guru menyimpulkan materi yang telah dipelajari. Lalu guru memberikan soal evaluasi (Tes Akhir Siklus II) dalam waktu 30 menit. Hasil tes tesebut antara lain :

Tabel 2. Ketuntasan Hasil Belajar Siklus II

\begin{tabular}{cccc}
\hline No & Hasil Belajar & Jumlah & Persentase \\
\hline 1 & Tuntas & 17 & 85 \\
\hline 2 & Tidak Tuntas & 3 & 15 \\
\hline & Jumlah & 21 & 100 \\
\hline
\end{tabular}

Tabel 2. di atas menunjukkan bahwa jumlah siswa yang belum tuntas makin sedikit yaitu sebanyak $3(15,00 \%)$ orang siswa sedangkan siswa yang telah mencapai ketuntasan dalam belajar lebih banyak yaitu 17 (85,00 \%) orang siswa dengan nilai rata-rata kelas 80,40. Kesimpulan dari proses pembelajaran siklus II adalah hasil tes belajar siswa yang memperoleh nilai KKM $\geq 72$ sebanyak $17(85 \%)$ orang siswa dari 20 orang siswa seluruhnya. Hal ini disebabkan guru memperhatikan/membimbing dan sering memotivasi siswa sehingga siswa lebih aktif dalam proses pembelajaran.

Hasil pengamatan aktivitas siswa pada siklus II yaitu siswa tampak serius memperhatikan penjelasan guru (peneliti) dan sudah berani mengajukan pertanyaan maupun pendapat, siswa sudah aktif belajar dalam kelompok asal dan kelompok ahli, siswa sudah terbiasa dengan teman-teman satu kelompok sehingga komunikasi berjalan dengan baik, pada waktu akan presentasi, siswa sudah terlihat siap dan percaya diri untuk mewakili presentasi, siswa sudah percaya diri dalam mengerjakan tes akhir siklus II, kemajuan siswa yang ditunjukkan dengan meningkatnya prestasi 
hasil belajar mereka. Hasil pengamatan aktivitas guru yaitu guru selalu memantau kegiatan siswa, mengecek dan memperhatikan siswa serta memotivasi agar siswa selalu lebih baik, guru memberikan umpan balik siswa untuk aktif dan tidak takut dalam mengemukakan pendapat.

Target meningkatnya hasil belajar siswa ditandai dengan rata-rata nilai hasil belajar siswa di kelas di atas KKM (72) yaitu 80,40 dengan ketuntasan belajar klasikal 85,00 \% sudah tercapai pada siklus ini. Sehingga memutuskan untuk tidak lagi diadakan siklus berikutnya. Secara keseluruhan hasil penelitian yang telah dimulai dari tahap prasiklus, siklus I dan siklus II dapat digambarkan sebagai berikut :

Tabel 3. Ketuntasan Hasil Belajar dari Prasiklus Sampai Dengan Siklus II

\begin{tabular}{ccccc}
\hline No & Hasil Belajar & Tuntas & Tidak Tuntas & $\begin{array}{c}\text { \% } \\
\text { Ketuntasan }\end{array}$ \\
\hline 1 & Pra Siklus & 5 & 15 & 25 \\
\hline 2 & Siklus I & 11 & 9 & 55 \\
\hline 3 & Siklus II & 17 & 3 & 85 \\
\hline
\end{tabular}

Selanjutnya agar lebih jelas peningkatan hasil belajar siswa dari prasiklus sampai dengan siklus II, dapat dilihat pada grafik 1.

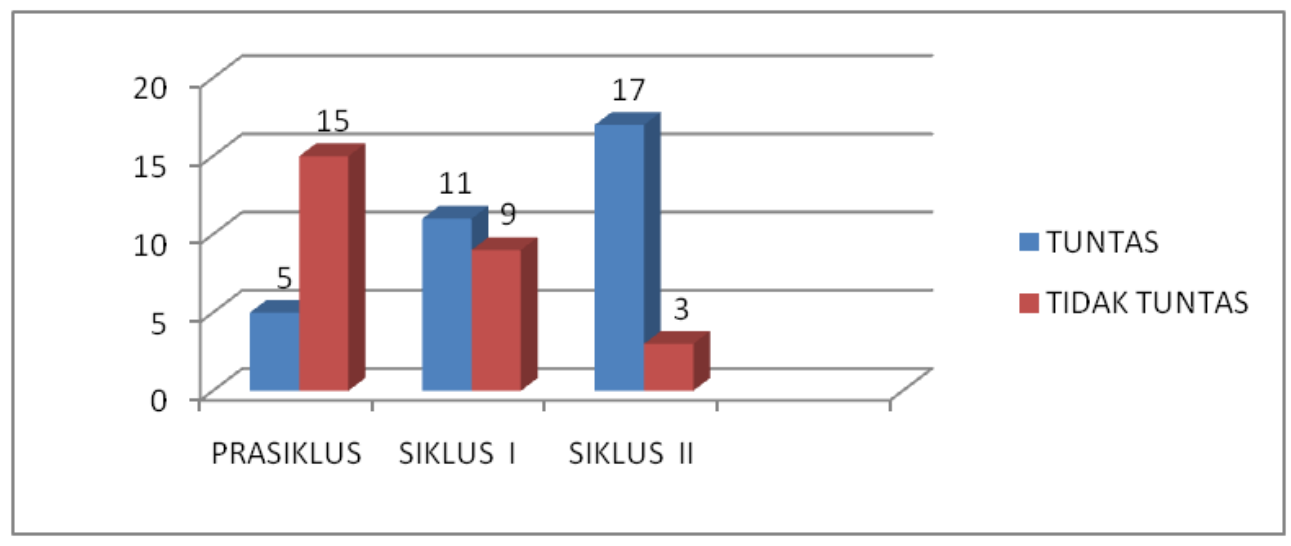

\section{Gambar 1. Hasil Belajar Prasiklus Sampai Dengan Siklus II}

Tabel 3 dan grafik 1 di atas menunjukkan bahwa sebelum pelaksanaan pembelajaran dengan penerapan model pembelajaran cooperative learning tipe jigsaw (prasiklus), jumlah siswa yang mencapai ketuntasan adalah 5 orang siswa atau sebesar 25,00\%. Kemudian setelah dilaksanakan pembelajaran dengan penerapan model pembelajaran cooperative learning tipe jigsaw terjadi peningkatan hasil belajar pada pembelajaran siklus I meningkat menjadi 11 (55,00\%) orang siswa dan pada siklus II meningkat menjadi $17(85,00 \%)$ orang siswa. Dari hasil tersebut diketahui bahwa pembelajaran dengan penerapan model cooperative learning tipe jigsaw meningkatkan persentase ketuntasan belajar dengan signifikan. Hal ini menunjukkan pemahaman siswa dalam pembelajaran dengan penerapan model cooperative learning tipe jigsaw dapat meningkatkan hasil belajar fisika siswa.

\section{SIMPULAN}

Berdasarkan deskripsi data dan analisis penelitian dapat disimpulkan bahwa pembelajaran fisika dengan penerapan model cooperative learning tipe jigsaw dapat meningkatkan hasil belajar fisika siswa kelas XII IPA 3 SMA Negeri 3 Bengkalis. Ini dibuktikan dengan adanya peningkatan persentase ketuntasan belajar siswa yaitu dengan meningkatnya nilai tes akhir dari masing-masing siklus. Meskipun masalah yang dihadapi dalam penerapan pembelajaran cooperative learning tipe 
jigsaw yaitu perlu banyak waktu dalam penerapannnya serta suasana kelas sedikit ramai saat presentasi masing-masing kelompok, namun guru harus benar-benar paham menyiapkan pembelajaran dengan sebaik mungkin, agar materi tersampaikan secara maksimal dan memperkaya variasi mengajar, mengenal model-model pembelajaran sehingga dapat mengantisipasi kejenuhan yang dialami oleh siswa dalam proses pembelajaran yang pada akhirnya dapat meningkatkan hasil belajar fisika siswa.

\section{REFERENSI}

Abdurrahman. (2003). Pendidikan bagi anak yang berkesulitan belajar. Jakarta : Rineka Cipta.

Arends, R. (2008). Cooperative learning : mempraktekkan cooperative learning di kelas. Jakarta : PT. Grasindo.

Aunurrahman. (2011) Belajar dan pembelajaran. Bandung : Alfabeta.

Depdiknas. (2004). Rambu-rambu penetapan ketuntasan belajar minimal dan analisis hasil pencapaian standar ketuntasan belajar. Jakarta : Depdiknas.

Dimyati., \& Mujiono. (2006). Belajar dan pembelajaran. Jakarta : Rineka Cipta.

Hanafiah, N., \& Suhana, C. (2010). Konsep strategi pembelajaran. Bandung : Refika Aditama.

Isjoni. (2011). Cooperative learning : mengembangkan kemampuan belajar berkelompok. Bandung : Alfabeta.

Komalasari, K. (2011). Pembelajaran kontekstual konsep dan aplikasi. Bandung : PT. Refika Aditama.

Rusman. 2012. Model-Model Pembelajaran : mengembangkan profesionalitas guru. Ed 2. Jakarta: Rajawali Pers.

Sardiman. (2011). Interaksi dan motivasi belajar mengajar. Jakarta : Rajawali Press.

Siregar, E., \& Nara, H. (2010. Teori belajar dan pembelajaran. Bogor : PT. Ghalia Indonesia.

Sudjana, N. (1990). Dasar-dasar proses belajar mengajar. Bandung : Remadja Rosdakarya.

Slavin, R.E. (2005). Cooperative learning, teori, riset \& praktik. Bandung : Nusa Media.

Suprijono, A. (2011). Model-model pembelajaran. Jakarta : Gramedia Pustaka Jaya.

Syah, M. (2002). Psikologi pendidikan. Jakarta : Depdikbud.

Tim. (2008). Panduan lengkap KTSP (kurikulum tingkat satuan pendidikan). Yogyakarta : Pustaka Yustisia.

Winkel, W.S. (1996). Psikologi pengajaran. Jakarta : Gramedia. 